Part II. Physical activity of social and professional groups

Dział II. Aktywność fizyczna grup społecznych i zawodowych

\title{
GENDER DIFFERENCES IN PHYSICAL ACTIVITY AMONG SECONDARY SCHOOL STUDENTS IN THE VISEGRAD COUNTRIES (V4)
}

\section{RÓŻNICE MIEDZY PŁCIAMI W ODNIESIENIU DO AKTYWNOŚCI FIZYCZNEJ WŚRÓD UCZNIÓW SZKÓŁ ŚREDNICH W KRAJACH GRUPY WYSZEHRADZKIEJ (V4)}

\author{
Pongrác Ács ${ }^{1(\mathrm{~A}, \mathrm{~B}, \mathrm{~B}, \mathrm{D}, \mathrm{E}, \mathrm{F}, \mathrm{G})}$, Józef Bergier ${ }^{2(\mathrm{~A}, \mathrm{D}, \mathrm{E}, \mathrm{F}, \mathrm{G}, \mathrm{G})}$, Ferdinand Salonna ${ }^{3(\mathrm{~A}, \mathrm{D}, \mathrm{E}, \mathrm{F}, \mathrm{G}, \mathrm{G})}$, \\ Jan Junger ${ }^{4(A, D, E, F, G)}$, Csaba Melczer $^{1(A, D, E, F, G)}$, Alexandra Makai $^{1(A, B, C, D, E, G)}$ \\ ${ }^{1}$ University of Pécs, Faculty of Health Sciences, Pécs, Hungary \\ ${ }^{2}$ Pope John Paul II State School of Higher Education in Biała Podlaska, Poland \\ ${ }^{3}$ Palacký University of Olomouc, The Czech Republic \\ ${ }^{4}$ University of Presov in Presov, Slovakia
}

Authors' contribution Wkład autorów:

A. Study design/planning zaplanowanie badań B. Data collection/entry zebranie danych C. Data analysis/statistics dane - analiza i statystyki D. Data interpretation interpretacja danych E. Preparation of manuscript przygotowanie artykułu F. Literature analysis/search wyszukiwanie i analiza literatury G. Funds collection zebranie funduszy

\section{Summary}

Background. Physical inactivity is also a significant problem in East-Central Europe and Hungary where $20 \%$ of the population does sports regularly while $53 \%$ of them never, in turn, $24 \%$ of the people does sports few times monthly. Insufficient physical activity is an increasing public health problem among young people and adolescents. Several types of research examined the quality and extent of physical activity related to different factors (social demographic, psychosocial, and lifestyle, etc.). Material and methods. Interviewing was carried out from April to June 2015 at the same time in each Visegrad country. IPAQ extended physical activity questionnaire and a self-edited questionnaire were used to assess nutritional and activity habits (In order to evaluate data, INDARES software, and paper-based questionnaires were used for 2145 persons from different secondary schools). Results. In low PA level category, male students were rather found while in high PA level category, male students showed higher ratios than females. From $56.7 \%$ to $77.8 \%$ of male students occurred in high PA level category opposite to female students where this rate was from $42.4 \%$ to $67.4 \%$. We found significant gender differences in total MET/week values $(p<0.001)$ in the V4 countries. Conclusions. We found significant differences in the Visegrad countries and between sexes. These differences draw the attention to improving deficiencies in physical activity of secondary school students with well-defined risk group interventions.

Keywords: physical activity, IPAQ, adolescents, Visegrad countries

\section{Streszczenie}

Wprowadzenie. Brak aktywności fizycznej to poważny problem występujący w Europie Wschodniej i Środkowej, a także na Węrzech, gdzie $20 \%$ ludności nie uprawia regularnie żadnego sportu, podczas gdy 53\% ludzi nie uprawia sportu wcale, natomiast $24 \%$ populacji uprawia sport kilka razy w miesiącu. Zbyt niska aktywność fizyczna to rosnący problem z zakresu zdrowia publicznego wśród młodych ludzi i nastolatków. Przeprowadzono już szereg różnego rodzaju badań związanych z jakością i zakresem aktywności fizycznej w odniesieniu do wielu czynników (socjodemograficznych, psychospołecznych oraz związanych ze stylem życia itd.). Materiał i metody. W okresie od kwietnia do czerwca 2015 przeprowadzono wywiady równolegle w każdym z krajów grupy Wyszehradzkiej. W badaniu wykorzystano kwestionariusz IPAQ z rozszerzonym zakresem aktywności fizycznej oraz stworzony przez autorów kwestionariusz w celu dokonania oceny nawyków żywieniowych oraz tych związanych z aktywnością fizyczną (w celu oceny danych wykorzystano oprogramowanie INDARES oraz wydrukowane kwestionariusze w przypadku 2145 uczniów z różnych szkół średnich). Wyniki. W zakresie niskiej aktywności fizycznej prym wiedli uczniowie płci męskiej, podczas gdy w kategorii wysokiego poziomu aktywności fizycznej, uczniowie płci męskiej wykazywali wyższy poziom niż uczennice. Między 56,7\% a 77,8\% uczniów płci męskiej znalazło się w kategorii wysokiej aktywności fizycznej, w przeciwieństwie do uczennic, w przypadku których ten wskaźnik odnotowano na poziomie między $42,4 \%$ a $67,4 \%$. Autorzy badania wykazali także znaczne różnice pod względem płci w całkowitych wartościach MET/tydzień $(\mathrm{p}<0,001) \mathrm{w}$ krajach V4. Wnioski. Wykazano znaczne różnice w krajach grupy Wyszehradzkiej w odniesieniu do płci. Różnice te kierują naszą uwage na konieczność ulepszenia braków związanych z aktywnością fizyczną uczniów w szkołach średnich, w obliczu istnienia dobrze zdefiniowanych działań wobec konkretnych grup ryzyka.

Słowa kluczowe: aktywność fizyczna, IPAQ, młodzież, kraje grupy Wyszehradzkiej
Tables: 2

References: 21

Submitted: 31.05 .2016

Accepted: 06.07.2016

Acs P, Bergier J, Salonna F, Junger J, Melczer C, Makai A. Gender differences in physical activity among secondary school students in the Visegrad countries (V4). Health Problems of Civilization 2016; 10(3): 21-29. doi: 10.5114/hpc.2016.61363.

Address for correspondence / Adres korespondencyjny: Pongrác Ács, University of Pécs, Faculty of Health Sciences, Pécs, Hungary, H-7621 Pécs, Vörösmarty u. 4, e-mail: pongrac.acs@etk.pte.hu, phone: 003672535980

Copyright: ( 2016 Pope John Paul II State School of Higher Education in Biała Podlaska. This is an Open Access journal, all articles are distributed under the terms of the Creative Commons Attribution-NonCommercial-ShareAlike 4.0 International (CC BY-NC-SA 4.0) License (http://creativecommons.org/licenses/by-nc-sa/4.0/), allowing third parties to copy and redistribute the material in any medium or format and to remix, transform, and build upon the material, provided the original work is properly cited and states its license. 


\section{Introduction}

Physical inactivity causes 600000 deaths in the European Union every year, according to the statistical estimations [1]. Physical inactivity is a crucial problem in East-Central Europe and Hungary, where 20\% of the population does sports regularly while $53 \%$ of them never, in turn $24 \%$ of the people does sports few times monthly. Therefore, $77 \%$ of the population is insufficiently active. [2] Insufficient physical activity among young people and adolescents is an increasing public health problem. More than $50 \%$ of girls and 33\% of boys in Poland show fairly low physical activity, thus in the European Union, including Poland, approximately 2/3 of adolescents do not attain the recommended level of physical activity [3]. The importance of the physical activity and child obesity has been proved by several studies $[4,5,6,7,8]$. Even so, the achievements of civilization and urbanization generate the marginalization of sports activities [9].

Several studies examined the quality and extent of physical activity related to different factors (social demographic, psychosocial, and life style, etc.). Trost et al. (2008) did a research among primary school students $(n=147)$ from the age of 9 to 12. They examined them according to their BMI, sex, and sporting facilities. Also, their rate of access to sports was assessed. Mean age: 10.1 (SD: 0.7). The test was done by Actigraph ${ }^{1}$ for three years. Measurements were taken in spring and autumn each year. The intensity and duration of the physical activity were customized with the help of the instrument. Concerning these factors, the following categories were set up. Sedentary (SED), light (LPA), moderate (MPA), vigorous (VPA), meanly vigorous (MVPA). The results showed that respondents spent $42.6 \mathrm{~min}$. with sedentary, $40.8 \mathrm{~min}$. with light, $13.4 \mathrm{~min}$. with moderate, and 5.3 min. with vigorous activities. In gender distribution, it was found that participants in sedentary, vigorous, and meanly vigorous categories were boys. On weight, $16.5 \%$ of the respondents were overweight, $22.8 \%$ of them were obese [10].

Janssen et al. (2005) examined the prevalence of overweight, obesity, nutrition, and physical activity patterns among schoolchildren in 34 countries (mostly European countries). 137593 participants, aged 10-16, took part in the research from 2001 to 2002. The extent of overweight and obesity was defined by the international child BMI. The results showed that the prevalence of overweight and obese young people was the highest in Malta and the US. The lowest values were found in Lithuania and Latvia. Besides these facts, the incidence of obesity was particularly high in North America, Great Britain, and South-West Europe. In most countries, the level of physical activity was rather low. In $91 \%$ of the countries examined, there were more overweight young people than contemporaries with average weight. Adolescent overweight can be considered as a global phenomenon therefore, it seems to be essential for us to elaborate strategies increasing physical activity [11].

In Slovakia, a similar research was carried out to examine the correlation between lower socioeconomic position, addiction, and physical activity. Health behavior matures until the late childhood or in adolescence. The aim of the study was to reveal the health behavior of adolescences between the age of 15 and 19 in the light of the social and economic situation. 31 secondary schools participated in the study. The first part of the examination was carried out in 1998. The sample comprised of 844 students, mean age: 14.9 years. The longitudinal study was accomplished in 2002. The mean age of the sample was 18.8 years. Smoking, alcohol consumption habits, and the frequency of physical activity were examined in the light of four socioeconomic indicators. The four indicators were the following: the education level, the employment position of the adolescents, the parents' highest education level, and employment status. The results showed that health behavior significantly improved after the four-year-follow-up. The greatest improvement was observed in the smoking habits of boys. Regarding health behavior, a significant difference was found in the socioeconomic factors, in the 15-19 age group. There was no difference between health behavior and the socioeconomic position of the 15-year-old students, but these differences became more apparent until the age of 19. Concerning men, it was found that the worse their socioeconomic situation was, the more common addiction became, and the lower their level of physical activity was. In women, reverse results were found [12]. This fact could be useful to improve adolescents' physical activity according to different risk groups.

Stelzer et al. (2004) examined physical education attitudes in 6 high schools of four countries (Czech Republic, Austria, Great Britain, and the US). Each secondary school was a public, city school, and the interviewees were local inhabitants. A total of 1107 students participated in the study (487 from the Czech Republic, 303 from the US, 217 from Great Britain, and 100 from Austria). The participants' age was between 14 and 20 years (mean age: 16.8), but $90 \%$ of the participants in the sample belonged to the $16-18$ age group. The sample comprised of 41.2\% females and 57.9\% males. Adams Scale was applied to measure the attitude to physical education. The total data of the issues on the 7-point scale showed positive attitudes to physical education in the four countries. The individual examination of each country showed a more positive attitude in the Czech Republic (average

$\overline{{ }^{1} \text { http://www.actigraph }}$ corp.com/ (2015 Sept 15). 
score: 87.9 max. 112), Austria (average score: 84.9) than in Great Britain (81.1) and in the US (82) among the respondents $(\mathrm{p}<0.001)$. Regarding sexes, mainly boys gave positive answers. According to the total scores, the lowest score was 56, and the highest score was 84.7. Significant difference was found in the gender distribution. In the case of boys, the mean score was max. 86, while this score was only 82 for girls. The difference between the two scores was only 4 , but it was significant $(\mathrm{p}<0.001)$ [13].

Based on the above results and further research, the attitude to physical activity varies with the different socio-demographic factors, such as gender and culture [14]. The aim of our research was to examine differences and similarities in physical activity and nutrition habits in the four Visegrad countries among adolescents, secondary school students.

\section{Material and methods}

Quantitative, cross-sectional survey research.

Interviewing was carried out from April to June 2015 at the same time in each country. IPAQ extended questionnaire and a self-edited questionnaire were used to assess nutritional and activity habits [15]. In order to evaluate data, INDARES software, and paper-based questionnaires were used. Ethical principles of the Helsinki Declaration were taken into consideration. Written consent from parents was asked for the participation of children under 18 in the research. Participation was voluntary and anonymous for young people. Interviewing was carried out online with university students and in a paper-based form with secondary school students with the help of assistants in classes of the form master.

Assessment was accomplished on the health status, physical activity, nutrition habits among young people (secondary school students) in the V4 countries. It assesses the activity of young people, the basis of their nutrition, their relation to sports, if they do any sports or what sports they prefer.

Participants: Participant countries were the Czech Republic (Palacky University, Olomouc) Poland (Pope John Paul II State School of Higher Education in Biala Podlaska), Slovakia (University of Presov in Presov, Faculty of Sport) and Hungary (University of Pécs Faculty of Health Sciences, Pécs). The number of the participants in each country accounted for 1200 persons from the secondary school and university population at the beginning of the research. The sample consisted of 600 secondary school and 600 university students on average in each country in which the gender distribution was equal and the distribution per year was proportional. For statistical analysis, the research comprised of 4382 persons as a total, 2145 persons from different secondary schools.

To measuring physical activity, we used the International Physical Activity Questionnaire extended and selfadministered versions. According to the IPAQ, data of the physical activity categories were as follows: low with 600/MET/week activity level; medium with 600-1500/MET/week; and high with above 1500/MET/week. IPAQ differentiates sedentary, moderate, and vigorous activities to which different MET values are associated, such as sports or household chores. The individual's physical activity per week equals with the MET value multiplied with the duration of the activity (MET/week) [16,17].

In our analysis, the independent variables were sex, age, domicile, body height, body mass (self-reported), education. Dependent variables were settled by IPAQ extended data measuring physical activity. Three physical activity categories were differentiated in agreement with international standards: low, moderate, and high physical activities.

Data analysis was carried out by SPSS 22.00 statistical software. Besides descriptive statistics, chi-square test, and Mann-Whitney U test, Kruskal-Wallis tests were used for analysis of the differences between countries. Data distribution was tested by Kolmogorov-Smirnov test. As data distribution was not considered as normal, we applied non-parametric tests. The significance level was determined by $\mathrm{p}<0.05$.

\section{Results}

The sample size of secondary school students was 2145, including 877 male and 1268 female students. The mean age of the secondary school respondents was $17.12 \pm 1.53$. The average weight of female students in the four countries is from $57.26-60.28 \mathrm{~kg}$, and of males from 69.45 to $72.39 \mathrm{~kg}$. The average height of females is from $165.62-167.01 \mathrm{~cm}$, and of males from 178.28 to $180.22 \mathrm{~cm}$. We examined BMI values based on the weight and height data of the secondary school students that were similar in the four countries, with a mean $21.34 \pm 3.37$ (Table 1). 
Table 1. Descriptive statistics

\begin{tabular}{|c|c|c|c|c|c|c|c|}
\hline & & $\begin{array}{c}\text { Male } \\
(n=877)\end{array}$ & $\% / S D$ & $\begin{array}{c}\text { Female } \\
(n=1268)\end{array}$ & $\% / S D$ & $\begin{array}{c}\text { Total } \\
(\mathrm{n}=2145)\end{array}$ & $\% / S D$ \\
\hline \multirow{4}{*}{ Gender } & Slovakia & 153 & $33.70 \%$ & 301 & $66.30 \%$ & 454 & $21.17 \%$ \\
\hline & Poland & 319 & $50.24 \%$ & 316 & $49.76 \%$ & 635 & $29.60 \%$ \\
\hline & Czech Republic & 128 & $25.40 \%$ & 376 & $74.60 \%$ & 504 & $23.50 \%$ \\
\hline & Hungary & 277 & $50.18 \%$ & 275 & $49.82 \%$ & 552 & $25.73 \%$ \\
\hline \multirow{4}{*}{$\begin{array}{c}\text { Weight } \\
\text { (kg) }\end{array}$} & Slovakia & 69.45 & 10.83 & 57.52 & 9.52 & 61.54 & 11.46 \\
\hline & Poland & 69.32 & 11.09 & 57.26 & 9.40 & 63.32 & 11.92 \\
\hline & Czech Republic & 72.39 & 12 & 60.28 & 11.32 & 63.43 & 12.66 \\
\hline & Hungary & 70.37 & 13.61 & 57.58 & 10.06 & 64.01 & 13.57 \\
\hline \multirow{4}{*}{$\begin{array}{c}\text { Height } \\
\text { (cm) }\end{array}$} & Slovakia & 178.85 & 8.95 & 166.96 & 6.39 & 170.97 & 9.25 \\
\hline & Poland & 179.60 & 7.16 & 165.99 & 6.00 & 172.83 & 9.49 \\
\hline & Czech Republic & 180.22 & 7.63 & 167.01 & 6.07 & 170.36 & 8.68 \\
\hline & Hungary & 178.28 & 7.56 & 165.62 & 6.58 & 171.97 & 9.50 \\
\hline \multirow{4}{*}{ BMI } & Slovakia & 21.71 & 3.15 & 20.62 & 3.06 & 20.98 & 3.13 \\
\hline & Poland & 21.44 & 2.83 & 20.74 & 2.96 & 21.10 & 2.91 \\
\hline & Czech Republic & 22.27 & 3.38 & 21.6 & 3.97 & 21.78 & 3.84 \\
\hline & Hungary & 22,10 & 3.82 & 20.96 & 3.17 & 21.53 & 3.55 \\
\hline
\end{tabular}

\section{Physical activity level of secondary school students}

We examined the differences in physical activity level of secondary school students among the V4 countries where we found significant differences $\left(p<0.001, \chi^{2} 46.892\right)$. Also examining gender differences among the three physical activity categories we found significant differences in Slovakia and Poland. However, different PA level of males and females could be found in the Czech Republic and Hungary. A higher rate of low PA level of males was seen in every country, except for Poland where female students' (7.91\%) low PA level rate was higher than that of male students (3.76\%). However, male students rather occurred in the low PA level category. In the high PA level category, male students showed higher ratios than females. From 56.68\% to $77.78 \%$ of male students occurred in the high PA level category opposite to female students where this rate ranges from $42.41 \%$ to $67.44 \%$. Therefore, male students were more active than women, but female students mostly occurred in the moderate PA level category (Table 2).

Table 2. Physical activity level of V4 countries and gender differences

\begin{tabular}{|c|c|c|c|c|c|c|c|c|c|}
\hline & & Male & $\begin{array}{c}\text { country/ } \\
\text { column } \\
\%\end{array}$ & Female & $\begin{array}{c}\text { country/ } \\
\text { column } \\
\%\end{array}$ & Total & $\begin{array}{c}\text { country/ } \\
\text { column } \\
\%\end{array}$ & $\mathbf{p}$ & $\chi^{2}$ \\
\hline \multirow{4}{*}{$\begin{array}{c}\text { Low } \\
\text { physical } \\
\text { activity }\end{array}$} & Slovakia & 10 & $6.54 \%$ & 10 & $3.32 \%$ & 20 & $4.41 \%$ & 0.003 & 11.46 \\
\hline & Poland & 12 & $3.76 \%$ & 25 & $7.91 \%$ & 37 & $5.83 \%$ & $<0.001$ & 34.61 \\
\hline & Czech Republic & 7 & $5.47 \%$ & 14 & $3.72 \%$ & 21 & $4.17 \%$ & 0.087 & 4.89 \\
\hline & Hungary & 26 & $9.39 \%$ & 19 & $6.91 \%$ & 45 & $8,15 \%$ & 0.132 & 4.05 \\
\hline \multirow{4}{*}{$\begin{array}{c}\text { Moderate } \\
\text { physical } \\
\text { activity }\end{array}$} & Slovakia & 24 & $15.69 \%$ & 88 & $29.24 \%$ & 112 & $24.67 \%$ & & \\
\hline & Poland & 98 & $30.72 \%$ & 157 & $49.68 \%$ & 255 & $40.16 \%$ & & \\
\hline & Czech Republic & 40 & $31.25 \%$ & 158 & $42.02 \%$ & 198 & $39.29 \%$ & & \\
\hline & Hungary & 94 & $33.94 \%$ & 115 & $41.82 \%$ & 209 & $37.86 \%$ & & \\
\hline \multirow{4}{*}{$\begin{array}{c}\text { High } \\
\text { physical } \\
\text { activity }\end{array}$} & Slovakia & 119 & $77.78 \%$ & 203 & $67.44 \%$ & 322 & $70.93 \%$ & & \\
\hline & Poland & 209 & $65.52 \%$ & 134 & $42.41 \%$ & 343 & $54.02 \%$ & & \\
\hline & Czech Republic & 81 & $63.28 \%$ & 204 & $54.26 \%$ & 285 & $56.55 \%$ & & \\
\hline & Hungary & 157 & $56.68 \%$ & 141 & $51.27 \%$ & 298 & $53.99 \%$ & & \\
\hline
\end{tabular}

According to the IPAQ questionnaires data, we examined the summary of all physical activities of secondary school students regarding gender and countries in total MET / week. We found significant differences between the four countries $\left(\chi^{2}=131.814 \mathrm{p}<0.001\right)$. In Slovakia $(Z=-3.828 \mathrm{p}<0.001)$, Poland $(Z=-4.400, p<0.001)$ and $C z e c h$ Republic $(Z=-3.037, p=0.002)$ significant differences were seen between sexes, except for Hungary $(Z=-1.389$, $\mathrm{p}=0.165$ ) (Figure 1). 
Furthermore, we examined the job-and- household related, leisure time, and walking activities in MET/ week one by one. The job-related activities mean the time spent at school for secondary school students. The household activities mean the housework at home, around the house, or in the garden. Leisure time activity showed the preferred sport activities.

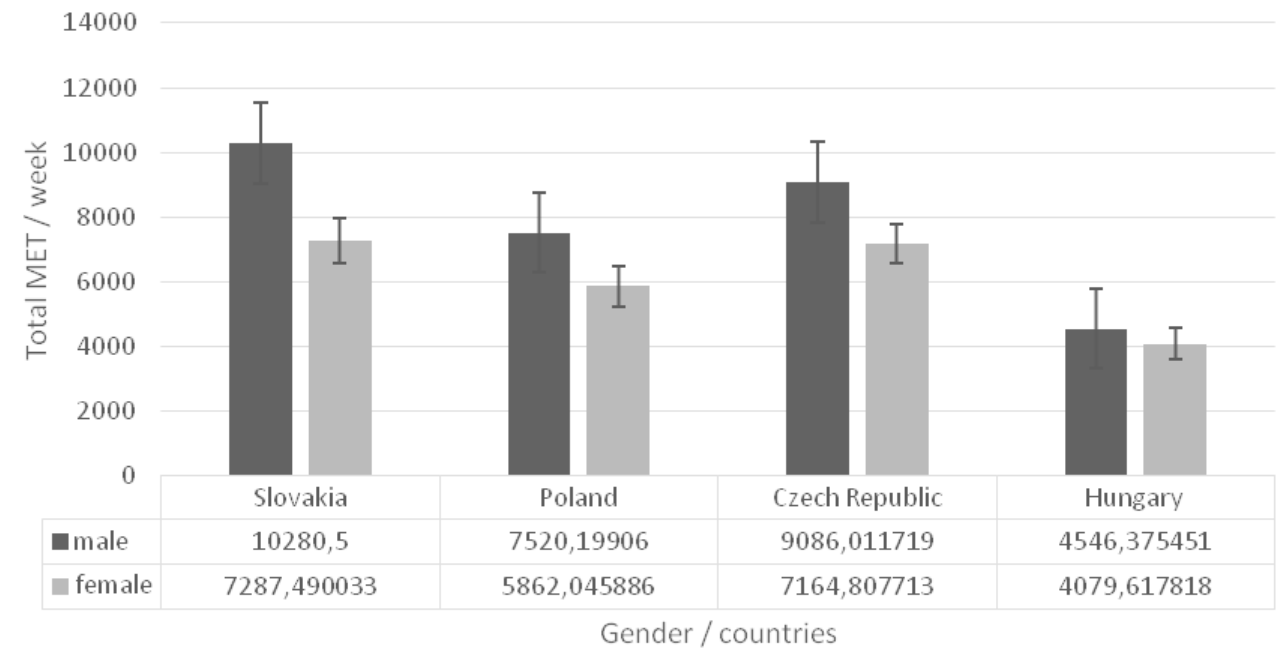

Figure 1. Total MET / week of secondary school students according to IPAQ

IPAQ questionnaire measures the job-related activities of the respondents, which means the time spent at school, such as physical education classes or time spent at breaks among the different classes for secondary school students. We found significant differences between countries. $\left(\chi^{2}=386.348, p<0.001\right)$. The highest rates show that Slovakian and Czech male students do more than 3000 MET/min weekly, than Slovakian females. Polish students and Czech females are the following in school time activities from 1813.815 MET/min to 2982.306 $\mathrm{MET} / \mathrm{min}$ and finally the Hungarian students rates are much lower than all the others. Their weekly job-related activities did not reach the $1000 \mathrm{MET} / \mathrm{min}$ that can be the result of the lack of everyday physical education classes for Hungarian students. Furthermore, examining gender differences, we found significant differences in every country (Poland: $Z=-2.974, p=0.003$, Czech Republic: $Z=-3.069 p=0.002$, Slovakia: $Z=-2.733, p=0.006$ ) except for Hungary $(\mathrm{Z}=-0.837, \mathrm{p}=0.402)$ (Figure 2).

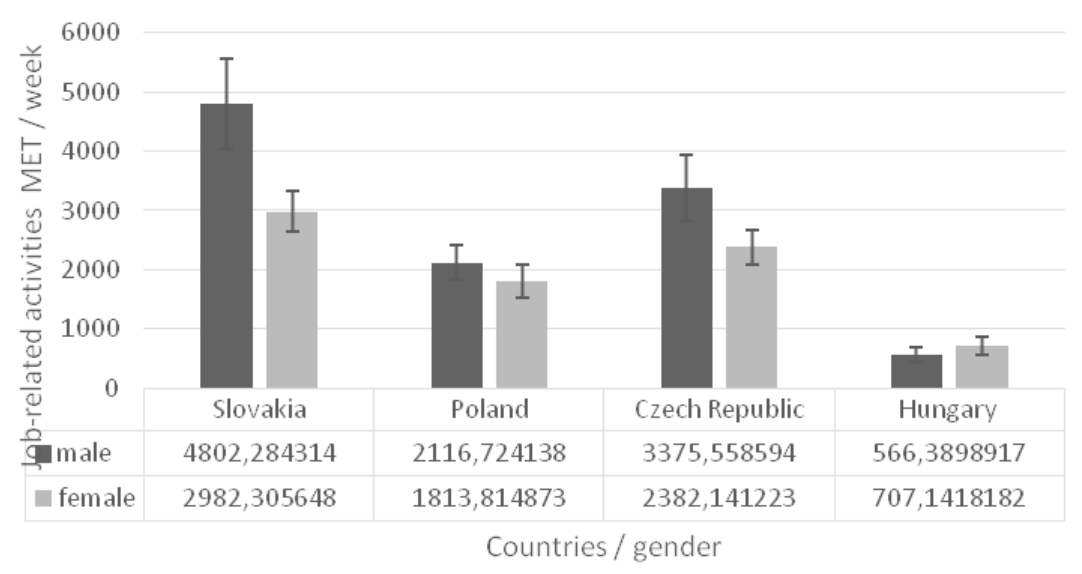

Figure 2. Job-related MET / week by gender and countries among secondary school students

Besides the time spent at school, the IPAQ questionnaire measured physical activities in the household, the time secondary school students spent with housework in and around their house. We found significant differences in the four countries $\left(\chi^{2}=16.226, p=0.001\right)$. In every country, male students did more activities at home than females except for Hungary where girls participated more in housework (1093.687 MET / week). The highest rates for MET / week was found among Czech males where 1661.480 MET / week was spent with housework. However, we did not find gender differences in the four V4 countries $(Z=-1.009 p=0.313)$. The 
reason for higher rates of male housework activities could be that males helped more their parents in vigorous housework activities (e.g. lifting heavy objects) than females.

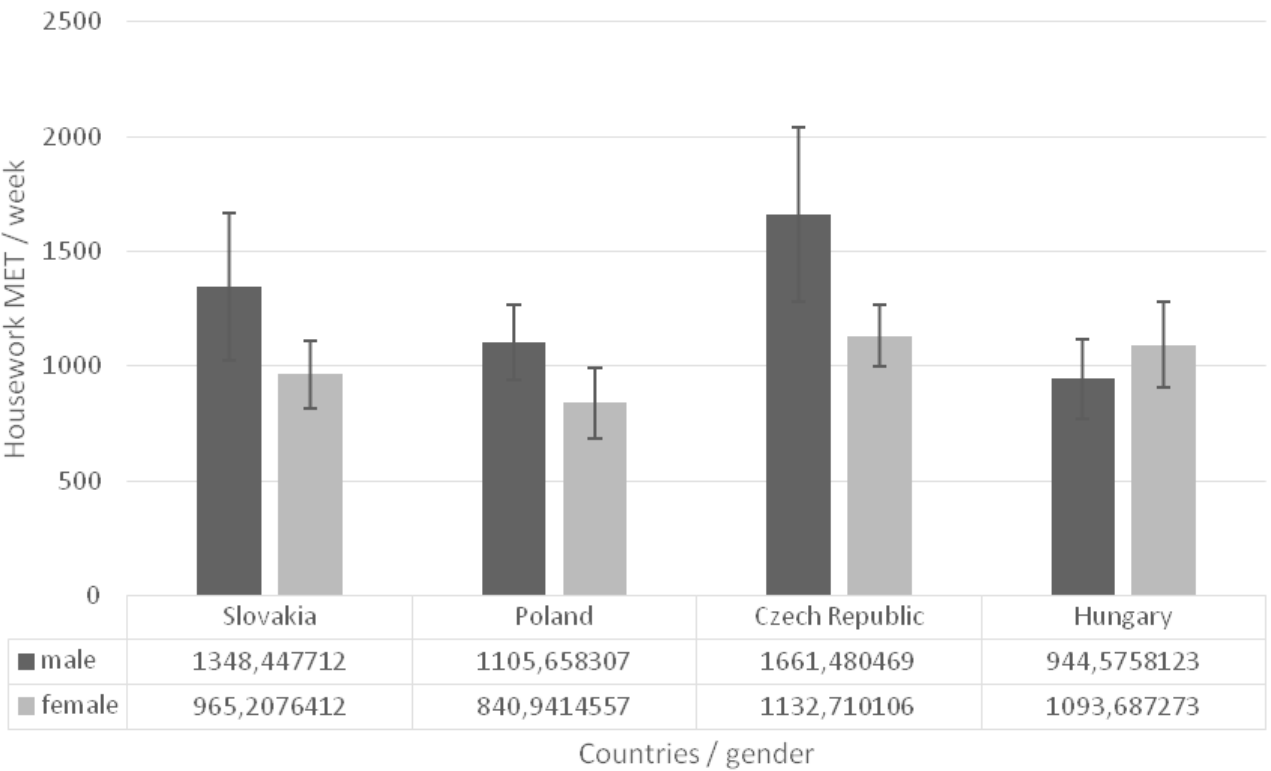

Figure 3. Housework MET / week among secondary school students in V4 countries

The time spent after school is important for secondary school students when they have much time to do sports, relax, or take part in any recreational activities. Our results proved the much higher rates of leisure time activities in MET/week. Every country's male or female students MET/min values in leisure time were more than 1685.487 MET/week that were much higher than that of other household activities. We found significant differences in the four countries $\left(\chi^{2}=11.710, p=0.008\right)$ and in sexes also $(Z=-3.313, p=0.001)$. Further research needed for examining the different types of activities (Figure 4).

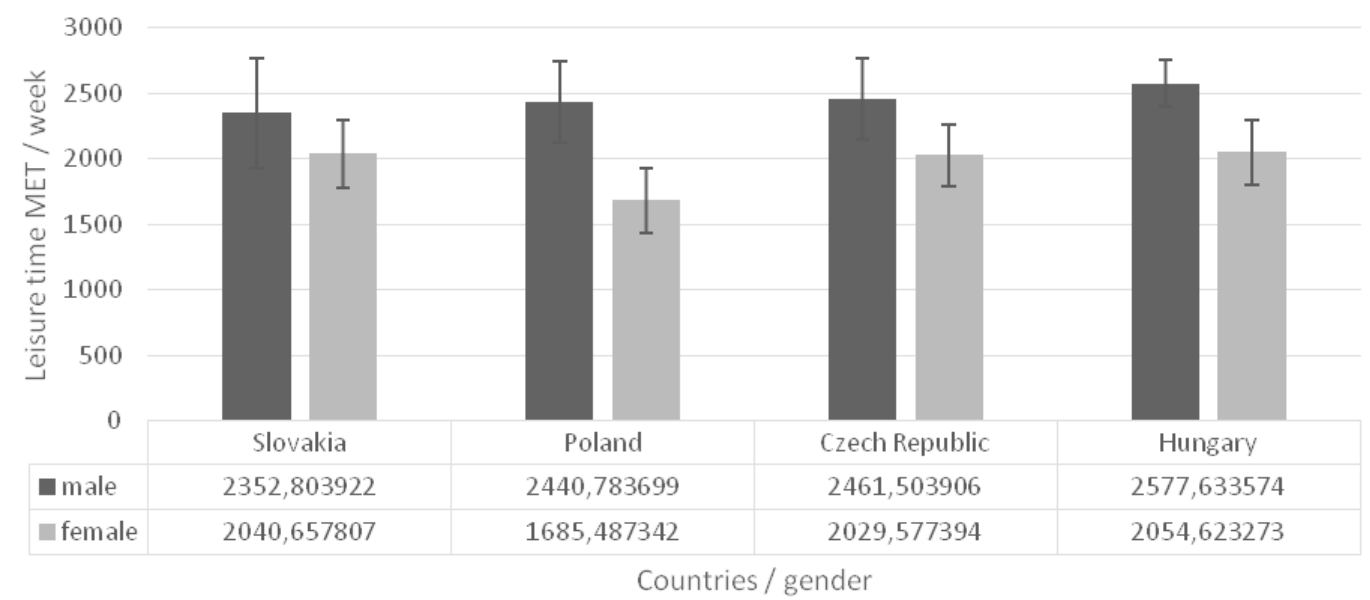

Figure 4. Leisure time activities among secondary school students in V4 countries

We found interesting results of Hungarian students' transportation activities. Rather low ratios were found in transportation that could demand further analysis to understand the differences. However, if we examine students' transportation habits from the other three countries, such as cycling or walking, we found significant gender differences in Poland ( $\mathrm{Z}=-2.757, \mathrm{p}=0.006)$ and Slovakia $(\mathrm{Z}=-2.159 \mathrm{p}=0.031)$, but not in the Czech Republic $(Z=-0.856, p=0.392)$. Therefore, Polish and Slovakian males are significantly more active walking and cycling than females. Therefore, every secondary school student should know about active transportation and take part in it. The schools or decision makers should draw the attention to it (Figure 5). 


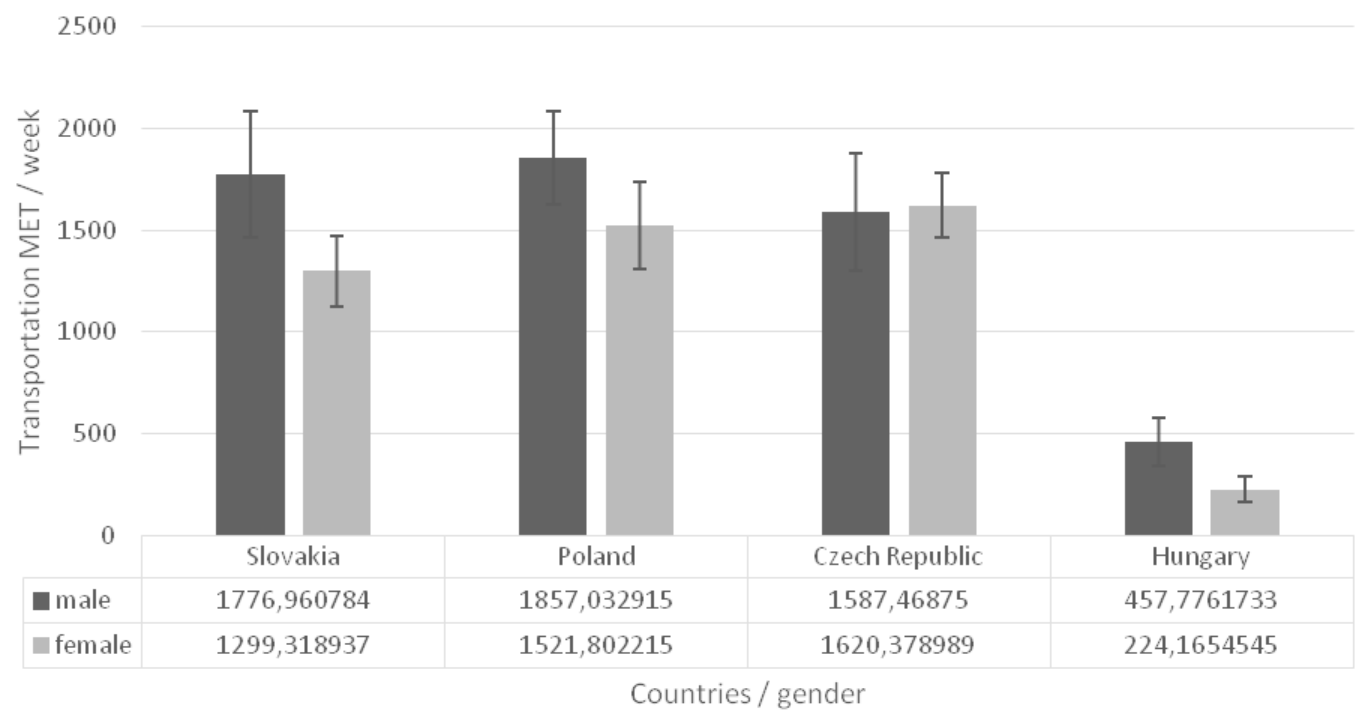

Figure 5. Transportation activities (walking) among secondary school students among V4 countries

\section{Discussion}

Several studies proved that physical activity showed different ratios of males and females, especially in young age. It can be 20 score difference for the benefit of young males. In Poland, 33\% of boys, and 50\% of girls had low or not sufficient physical activity. This fact involves severe problems and means a challenge for the present and the future in healthcare [3]. The lower physical activity ratios of female adolescents need special attention of persons, schools, or the government.

A study shows how regularity and quality of physical activity in adolescence affect activity habits in adulthood. Data were collected by a 10-year-long follow-up within a cross-sectional study. The study was carried out between 1998-2000, and 2008-2010 by a Yamax SW-701, and Omron HJ-105 odometer for seven days continuously, 10 hours per day (except for sleeping, hygiene activities). The age of the adolescents was between 14-18 years, and a total of 902 persons (410 boys, 492 girls) were included in the test. The results showed that there was no difference in the physical activity between the older and younger age groups among boys while the physical activity increased in the younger age groups of the girls. According to the results, 68\% of the 19982000 years sample and 55\% of the 2008-2010 years sample reached this value. Thus, the intensity of the physical activity is reduced by age among adolescents [18]. This fact verifies that everyone should take care of their health status and do sports activities regularly. Therefore, decision makers should draw the attention to it.

Several studies examined gender differences where males were found to be more active than females [19]. However, the activity level of young people reduces with age, especially among males [20]. Our results showed the highest rates of Slovakian and Czech male students with more than $3000 \mathrm{MET} / \mathrm{min} /$ week, followed by the Slovakian females, Polish students, and Czech females in school time activities from 1813.812 MET/min. to 2982.31 MET/min. Finally, the Hungarian students' rates were much lower than those of the others, as the weekly job-related activities did not reach the $1000 \mathrm{MET} / \mathrm{min}$. This fact can be associated with the lack of the everyday physical education classes of the Hungarian students. We found significant differences in every country examining gender differences. In every country, male students did more activities at home than females except for Hungary where girls participated more in housework (1093.69 MET / week). The highest MET / week was found among Czech males with 1661.48 MET / week spending with housework. These facts can draw the attention to the family based activities at home, such as housework chores together with parents.

Every country's male or female students MET/min values in leisure time are more than 1685.49 MET/week. These are much higher than other household activities. We found significant differences in the four countries $\left(\chi^{2}=11.710, p=0.008\right)$ Therefore, Polish and Slovakian males are significantly more active in walking and cycling than females. Active transportation is a rather important part of physical activity, but our results show that young people's and their parents' habits in transportation in the Visegrad countries are required to be improved.

It is also essential to focus on the cultural differences of different countries. A study found significant differences in the scores of the Czech, Austrian, British and American students. It can be concluded from this fact that there are important cultural differences between educational attitudes. These differences can be explained 
by the different structural factors. These differences can be attributed to the content of the curriculum, teacherstudent ratio, and the experts such as physical education teachers and trainers [21]. For example, two 90-minutelong physical education classes are necessary at school, in the Czech Republic each year [13]. This measure can be effective to improve the physical activity of young people and adolescents. Furthermore, everyday physical education was initiated for students in Hungary, 2014. This statute can be the first step to improve physical activity of secondary school students and do sports as a daily routine in their life. Many studies proved that regularity in sports is an essential factor, doing sports daily can be the most ideal activity [9]. Csányi quotes Williams' study that a student who is good at sports will do it more often. Therefore, it is not enough to do sports every day, but improving skills should be a useful way to convince the students that it is worth doing sports either at school or in leisure time. We should not forget the responsibility of the school and its teachers [20].

Furthermore, the environmental factor in physical activity can be determinative, such as parents' attitudes or the chance for the after-school activities (not sitting in front of the computer or television but doing sports on a local team) [20].

\section{Conclusion}

In our examination we proved the gender differences in V4 countries among the secondary school students and the low level of physical activity in certain gender groups. For young people to be healthy longer need to be paid more attention to be physically active. To improve secondary school students' physical activity school and family-based interventions are also necessary that can build physical activity into their daily routine.

\section{Acknowledgements}

This study was conducted within the framework of the project "Physical and recreational activity as well as diet of young people from V4 countries", co-financed by Visegrad Fund.

We would like to express our appreciation to the Visegrad-Fund for providing a chance to carry on the study, the leaderships of the partner universities, and the colleagues participating in the research. A special acknowledgement goes to Józef Bergier, the leader of the project.

\section{- Visegrad Fund

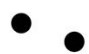

\section{References:}

1. Edwards P, Tsouros A. The solid facts: promoting physical activity and active living in urban environments. The role of local governments. WHO European Office, Geneva; 2006.

2. Ács P, Hécz R, Paár D, Stocker M. A fittség (m)értéke - A fizikai inaktivitás nemzetgazdasági terhei Magyarországon (The ratio/value of fitness - the economic burden of physical inactivity nation Hungary). Közgazdasági Szemle (Hungarian Economic Review); 2011, 58, 7-8: 689-708 (in Hungarian).

3. Bergier J, Kapka-Skrzypczak L, Biliński P, Paprzycki P, Wojtyła A. Physical activity of Polish adolescents and young adults according to IPAQ: a population based study. Ann Agric Environ Med. 2012 Mar 23; 19(1): 10915.

4. Gunter KB, Nader PA, John DH. Physical activity levels and obesity status of Oregon Rural Elementary School children. Preventive Medicine Reports. 2015; 2: 478-482.

5. Anderson PM, Butcher KE. Childhood obesity: Trends and potential causes. In: The Future of Children, 2016; 16(1): 19-45.

6. Lobstein T, Frelut ML. Prevalence of overweight among children in Europe. In Obesity reviews [Internet]. 2003 [cited 2013 March 13] Č.4, p. 195-200. Available from: http://fds.oup.com/www.oup.com/ pdf/13/9780199571512_chapter1.pdf

7. Powell E, Woodfield LA, Nevill AM. Increasing physical activity levels in primary school physical education: The SHARP Principles Model. Preventive Medicine Reports. 2016; 3: 7-13. 
8. Gortmaker SL, Lee RM, Mozaffarian RS, Sobol AM, Nelson TF, Roth BA, et al. Effect of an after-school intervention on increases in children's physical activity. Med Sci Sports Exerc. 2012 Mar; 44(3): 450-7.

9. PavlikG. The role of the regular physical activity in the prevention of different diseases and in the preservation of health (A rendszeres fizikai aktivitás szerepe betegségek megelőzésében, az egészség megőrzésében), Health Sciences (Egészségtudomány) LIX. Évfolyam, 2. Szám, 1-16 (in Hungarian).

10. Trost SG, Rosenkranz RR, Dzewaltowski D. Physical activity levels among children attending after-school programs. Med Sci Sports Exerc. 2008 Apr; 40(4): 622-9.

11. Janssen I, Katzmarzyk PT, Boyce WF, Vereecken C, Mulvihill C, Roberts C, et al. Comparison of overweight and obesity prevalence in school-aged youth from 34 countries and their relationships with physical activity and dietary patterns, Obesity Reviews. 2005 May; 6(2): 123-32.

12. Salonna F, Dijk JP, Geckova AM, Sleskova M, Groothoff JW, Reijneveld SA. Social inequalities in changes in health-related behaviour among Slovak adolescents aged between 15 and 19: a longitudinal study. BMC Public Health. 2008 Feb 12; 8:57. doi: 10.1186/1471-2458-8-57.

13. Stelzer J, Ernest JM, Fenster MJ, Langford G. Attitudes toward Physical Education: A Study of High School Students from Four Countries - Austria, Czech Republic, England, and USA. College Student Journal. 2004; 38(2): 171-179.

14. Greenockle KM, Lee AA, Lomax R. The relationship between selected student characteristics and activity patterns in a required high school physical education class. Research Quarterly for Exercise and Sport. 1991; 61: 59-69.

15. www.ipaq.ki.se [internet] [cited 2015 Sept 15].

16. Lachat CK, Verstraeten R, Khanh le NB, Hagströmer M, Khan NC, Van Ndo A, et al. Validity of two physical activity questionnaires (IPAQ and PAQA) for Vietnamese adolescents in rural and urban areas. Int J Behav Nutr Phys Act. 2008; Jul 10(5): 37: 1-8.

17. Lee PH, Macfarlane DJ, Lam TH, Stewart SM. Validity of the international physical activity questionnaire short form (IPAQ-SF): A systematic review. International Journal of Behavioral Nutrition and Physical Activity. 2011; 8: 115.

18. Sigmundová D, Ansari WE, Sigmund E, Frömel K. Secular trends: a ten-year comparison of the amount and type of physical activity and inactivity of random samples of adolescents in the Czech Republic, BMC Public Health 2011; 11: 731-743.

19. Wasilewska M, Bergier J. Physical activity level of the youth in selected countries of the world. Health Problems of Civilization. 2015; 9(3): 39-46.

20. Csányi T. Physical activity of young people and determinates of their inactivity. (A fiatalok fizikai aktivitásának és inaktív tevékenységének jellemzői). New Pedagogical Review (Új pedagógiai szemle). 2010; 60(3-4): 115-128 (in Hungarian).

21. Figley GE. Determinants of attitudes toward physical education. Journal of Teaching in Physical Education; 1985, 4: 229-240. 